\title{
TOLERANSI MASYARAKAT MULTI ETNIS DAN mULtIAgama dalam ORganisasI sUBAK DI BAL
}

\section{TOLERANCE OF MULTIETHNICS AND MULTIRELIGIONS SOCIETY IN SUBAK ORGANITATION AT BALI}

\author{
Oleh I Gusti Ayu Armini \\ Balai Pelestarian Nilai Budaya Bali, NTB, NTT \\ Alamat: Jl. Raya Dalung-Abianbase No.107 Dalung Kuta Utara Badung Bali \\ E-mail:armini55@yahoo.com
}

\begin{abstract}
Abstrak
Subak merupakan organisasi pertanian di Bali, yang identik dengan masyarakat Bali yang beragama Hindu. Hal ini tidak sepenuhnya benar, sebab organisasi subak di Bali bersifat multietnis dan multiagama. Masyarakat anggota subak bukan hanya masyarakat etnis Bali yang beragama Hindu, tetapi masyarakat etnis lain yang beragama Islam, Budha, Protestan, maupun Katolik. Perbedaan etnis dan agama yang dianut anggota subak mengharuskan adanya sikap toleransi masing-masing etnis dan agama anggota pendukung organisasi subak. Proses toleransi berjalan dengan baik dalam aktivitas subak, sehingga keberadaan lembaga subak tetap ajeg sampai saat ini. Secara khusus, kajian ini bertujuan mendeskripsikan kehidupan multietnis dan multiagama dalam kegiatan subak di Bali. Lebih lanjut, kajian ini diharapkan bermanfaat sebagai sumber informasi bentuk-bentuk adaptasi dan toleransi yang diterapkan pada tataran organisasi yang berbeda etnis dan agama. Dengan harapan, proses toleransi demikian dapat digunakan sebagai salah satu rujukan dalam menata kehidupan masyarakat multikultur di Indonesia. Kajian tentang toleransi menerapkan metode kualitatif dipadukan dengan analisis interpretatif.
\end{abstract}

Kata kunci: etnis, agama, organisasi subak, toleransi.

\begin{abstract}
Subak is an agricultural organization in Bali, which is identical to the Balinese with its Hindu religion. This is not entirely true, because subak organization is multiethnic and multi-religious. Community members of subak are not only Balinese ethnic with Hindus religion but other ethnic people such as Muslim, Buddhist, Protestant, and Catholic. Ethnic and religious affiliations of members of the subak organitation require tolerance attitude each ethnic and religious members of subak organitation. The process of tolerance goes well in subak activities, so the extention of subak institutions remain until now. This research aims to describe the tolerance of multiethnics and multireligions society in subak organitation. And then, this research expected use to information sources of tolerance forms in multiethnic and multireligion organitation. The process of tolerance had used for reference to life system for multicultural society in Indonesia. This research conducted by qualitative and interpretative analysis approach.
\end{abstract}


Keywords: ethnic, religion, subak organization, tolerance.

\section{A. PENDAHULUAN}

Selama ini masyarakat Bali dikenal sebagai masyarakat homogen, yakni etnik Bali yang identik dengan budaya Bali dan agama Hindu. Kenyataannya tidaklah demikian, sejak masa lampau Pulau Bali telah dihuni beberapa etnik dan agama berbeda. Selain masyarakat Bali yang beragama Hindu, juga bermukim etniketnik lain seperti Etnik Tionghoa yang menganut Agama Budha dan Kong Fu Tse (Konghuchu), Etnik Bugis dan Sasak yang beragama Islam, serta Etnik Eropa dan Bali beragama Kristen (Katolik dan Protestan). Dengan demikian dapat dikatakan bahwa sejak masa lampau sampai kini masyarakat Bali bukanlah masyarakat homogen, tetapi merupakan masyarakat heterogen dengan kondisi multietnis, multikultur, dan multiagama, yang relatif kompleks.

Perjalanan kehidupan multietnik dan berbeda agama pada masa lampau secara langsung memunculkan keragaman etnis dan budaya di Bali. Kantong-kantong etnis dan agama tertentu ditemukan di sejumlah wilayah Bali, baik di wilayah pesisir maupun di pedalaman. Biasanya, masingmasing etnis dan agama tersebut membentuk komunitas tersendiri dan mempertahankan agama serta adat-istiadat dari daerah asal masing-masing. Kondisi demikian ditemukan hampir di seluruh kabupaten di Bali. Beberapa contoh antara lain; masyarakat Desa Loloan Kabupaten Jembrana, masyarakat Desa Pegayaman Kabupaten Buleleng, masyarakat Bugis di Desa Serangan Denpasar, masyarakat Sasak di Desa Sindu Kabupaten Karangasem, dan lain-lain. Mereka hidup berkelompok dan mempertahankan kebiasaan hidup dan tradisinya secara turun-temurun. Masyarakat Desa Loloan dan Desa Serangan membuat rumah panggung serta tetap menjalankan syariat Islam di antara denyut kehidupan masyarakat sekitarnya.
Selain masyarakat muslim, kondisi multietnik dan multiagama di Bali juga didukung keberadaan masyarakat Tionghoa yang beragama Budha dan Kristen, serta masyarakat Etnis Bali yang menganut agama Protestan dan Katolik. Misalnya, masyarakat Desa Lampu Kintamani Kabupaten Bangli masih mencerminkan ciri-ciri kehidupan masyarakat Tionghoa. Masyarakat Bali yang beragama Katolik maupun Protestan di beberapa desa di Kabupaten Badung seperti Desa Tuka, Desa Dalung, Desa Abianbase. Di Kabupaten Tabanan, masyarakat Kristiani ada di Desa Nyuling, Piling, dan Mangesta. Di Kabupaten Jembrana, masyarakat Katolik dan Protestan ada di Desa Palasari dan Desa Warnasari. Sebagai Etnis Bali yang menganut Agama Kristen, dalam beberapa hal masih menjalankan tradisi dan polapola budaya Bali yang dipadukan dengan praktik Agama Kristen.

Ciri khas identitas masing-masing etnis pada kantong-kantong masyarakat multi etnis ditentukan berdasarkan kondisi geografis wilayah pemukimannya. Masyarakat yang mendiami wilayah pesisir umumnya merupakan masyarakat etnis Bugis atau Bajo yang bermata pencaharian sebagai nelayan. Adapun masyarakat yang tinggal di daerah pedalaman atau pegunungan terdiri atas masyarakat Bugis, Sasak, Madura, dan Tionghoa yang bermatapencaharian sebagai petani. Dalam keseharian mereka mempertahankan budaya masing-masing, sehingga ciri khas masyarakat Bugis tampak jelas dengan bangunan rumah panggung, masyarakat Tionghoa dengan bangunan rumah khas Cina. Kecuali masyarakat multi etnis yang bermukim di daerah perkotaan, tidak dapat diketahui dengan jelas ciri khas budaya yang menunjukkan identitasnya. Mereka umumnya menggeluti sektor-sektor informal sebagai pedagang atau pun penjual jasa. 
Dalam masyarakat multietnis dan multiagama kemampuan adaptasi dan toleransi menjadi pedoman pokok dalam berinteraksi dengan masyarakat sekitar. Masyarakat etnis Bali yang beragama Hindu merupakan masyarakat mayoritas diharapkan dapat bertoleransi terhadap kondisi keberagaman, sebaliknya etnis minoritas mampu beradaptasi terhadap kondisi sosial budaya masyarakat Etnis Bali. Hal ini sejalan dengan konsep principle of reprocity (prinsip-prinsip reprositas, timbal balik, saling memberi dan menerima) yang dikemukakan B. Mallinowski. Prinsip ini berfungsi memelihara solidaritas dan integritas dalam kehidupan bersama sebagai suatu masyarakat (Koentjaraningrat, 1980: 168). Kondisi demikian didukung oleh pendapat para ahli bahwa apabila dua masyarakat dan kebudayaan berada dalam lokasi yang sama, masyarakat minoritas di daerah tertentu akan mengikuti pola umum kehidupan masyarakat mayoritas. Dengan kata lain, kebudayaan minoritas akan mengikuti pola umum yang berlaku pada masyarakat mayoritas (Shadily,1993:8687). Dengan demikian, mereka dapat hidup berdampingan dan bekerjasama untuk kesejahteraan hidup mereka. Kerjasama tersebut meliputi berbagai aspek kehidupan termasuk memanfaatkan sumber daya alam dalam rangka memenuhi kebutuhan hidup.

Sehubungan dengan kondisi multietnis dan multikultur di Bali, tulisan singkat ini akan memaparkan bentukbentuk toleransi dan adaptasi kelompok mayoritas yakni etnis Bali yang beragama Hindu dan kelompok minoritas yakni etnis-etnis lain yang beragama non-Hindu, dalam tatanan organisasi subak. Masalah kajian ini mengkhusus pada tatanan organisasi subak, mengingat organisasi subak merupakan ajang pemanfaatan sumber alam bagi semua lapisan masyarakat yang bermata pencaharian sebagai petani. Sementara kegiatan pertanian dan subak di Bali identik dengan masyarakat Bali dan Agama Hindu, sedangkan kenyataannya ada beberapa etnis dan agama lain yang menetap dan bermata pencaharian sebagai petani. Mereka adalah kantong-kantong masyarakat non-Hindu yang bermukim di daerah-daerah pedalaman atau daerah pedesaan yang telah menetap di Bali secara turun-temurun. Di sini terjadi proses toleransi dalam aktivitas pertanian khususnya terkait pengaturan, pembagian lahan, dan pengairan sawah yang adil, baik kepada masyarakat etnis Bali yang beragama Hindu maupun masyarakat etnis lain yang beragama non-Hindu.

Aplikasi di lapangan menunjukkan bahwa pihak minoritas yang menjadi bagian dari organisasi subak cenderung beradaptasi menerima keputusan pihak mayoritas. Kondisi demikian merupakan hal wajar dalam kehidupan demokrasi organisasi subak. Namun, bila kondisi demikian dibiarkan berkembang dalam jangka waktu lama, dan tidak ada sikap toleransi antara pihak mayoritas dengan minoritas, ke depan hal ini dapat menjadi benih-benih konflik internal lembaga subak, bahkan mengarah pada konflik etnis dan agama. Sehingga, perlu adanya usahausaha mengidentifikasi potensi-potensi konflik untuk menghindari konflik skala besar di masa-masa mendatang. Dengan demikian identifikasi tentang toleransi masyarakat etnis Bali dan etnis-etnis lain di kantong-kantong masyarakat multietnis sangat penting guna mencegah konflik terbuka di masa-masa mendatang.

Penelitian ini menerapkan metode kepustakaan, observasi lapangan, dan wawancara. Metode kepustakaan diterapkan untuk menggali data sekunder, mendalami konsep, wawasan, serta rujukan substansi penelitian. Metode observasi digunakan untuk mengumpulkan data dalam pengamatan secara langsung satu kesatuan peristiwa yang berkaitan dengan toleransi subak. Metode wawancara digunakan untuk menjaring data primer dan informasi dalam proses wawancara dengan informan. Sebelum menjalankan proses wawancara terlebih dahulu 
disiapkan pedoman wawancara yang memuat pokok-pokok pertanyaan yang ada kaitannya dengan aktivitas subak pada masyarakat multietnis dan multiagama. Selanjutnya, data yang diperoleh diolah dan dianalisis menggunakan metode kualitatif dipadukan dengan analisis interpretatif.

\section{B. HASIL DAN PEMBAHASAN}

\section{Identifikasi Etnik dan Agama pada Masyarakat Bali}

Melalatoa(1995:642) mengelompokkan keberadaan etnis di Bali menjadi empat yakni etnis Bali Aga atau Bali Mula, Bali Datara, Loloan, dan Nyama Selam. Namun, Melalatoa tidak menyebut keberadaan orang-orang Tionghoa yang beragama Budha atau Konghuchu, orangorang Eropa dan Bali yang beragama Kristen. Tanpa mengabaikan pengelompokan etnis berdasarkan pendapat Melalatoa yang menguraikan bahwa masyarakat Bali terbagi menjadi empat kelompok etnis, dewasa ini ada beberapa kelompok etnis yang cukup dominan mewarnai kehidupan masyarakat multikultur di Bali, antara lain:

- Masyarakat Bali Aga adalah masyarakat Bali yang berada di beberapa wilayah (khususnya di wilayah pegunungan) dengan pola masyarakat dan tata cara kehidupannya relatif kurang mendapat pengaruh Hindu Majapahit. Mereka mempunyai struktur masyarakat tersendiri, tata upacara, tata bahasa, dan tidak mengenal sistem kasta.

\footnotetext{
- Masyarakat Bali Dataran adalah masyarakat Bali yang mendapat pengaruh dari Hindu Majapahit. Masyarakat Bali Dataran khususnya para Arya dan Brahmana datang ke Bali sejalan dengan ekspansi kerajaan Majapahit atau kedatangan Maha Patih Gajah Mada ke Bali. Masyarakat Bali Dataran adalah penduduk mayoritas di Bali saat ini.
}

- Masyarakat Loloan, merupakan perpaduan masyarakat Melayu dan Bugis tinggal di daerah pesisir sekitar Kota Negara Kabupaten Jembrana. Masyarakat ini menganut Agama Islam, mempunyai struktur masyarakat tersendiri, dan menggunakan Bahasa Loloan yang merupakan percampuran antara Bahasa Melayu dengan Bahasa Osing (Melalatoa, 1995:643). Arus kedatangan orang-orang Muslim ke Loloan semakin pesat setelah jatuhnya Makasar ke tangan Belanda pada 1667. Orang-orang Bugis datang ke Bali karena terusik harga dirinya oleh pihak penjajah. Mereka umumnya bermukim di daerah pesisir termasuk Desa Loloan atas izin raja. Tidak jarang dari mereka diangkat sebagai penglima kerajaan dan mempunyai hubungan kekerabatan dengan pihak penguasa karena proses perkawinan (wawancara dengan Ahmad Damanhuri di Loloan tanggal 28 Maret 2008).

- Masyarakat Nyama Selam. Nyama selam adalah sebutan bagi masyarakat muslim yang tinggal di Bali secara turun-temurun. Umumnya mereka berasal dari daerah Sulawesi Selatan, Sasak, maupun Madura (Melalatoa,1995:645). Keberadaan etnis Nyama Selam berawal sejak masuknya para ulama dari Kerajaan Islam di pesisir utara Pulau Jawa untuk menyebarkan Agama Islam ke Bali. Pada masa itu wilayah Bali berada di bawah kendali Kerajaan Gelgel pada masa pemerintahan Dalem Waturenggong pada 14601550. Misi para ulama tidak berhasil dengan baik karena raja tidak setuju dan tetap mempertahankan agama yang telah dianut secara turuntemurun. Meskipun demikian, Raja Gelgel tetap menghargai kedatangan masyarakat muslim kemudian diberikan tempat pemukiman yang sekarang disebut Kampung Jawa yang 
terletak di Desa Gelgel Klungkung (Sirikan, 1956: 103).

- Masyarakat Nasrani (Kristen Protestan dan Katolik) orang Bali menyebutnya Nyama Serani. Agama Nasrani khususnya Kristen Katolik mulai masuk ke Bali pada 1635, diperkenalkan oleh dua orang pastor dari Malaka (Hang, 1979: 23). Usaha kedua pastor ini tidak membuahkan hasil karena belum ada masyarakat Bali yang tertarik menganut Agama Katolik. Sementara itu, Agama Kristen Protestan mulai berkembang di kalangan masyarakat Bali pada 1873 dan berhasil mendapatkan pengikut di wilayah Kabupaten Badung. Kemudian dilanjutkan dengan penyebaran Agama Katolik yang memperoleh simpati pada golongan masyarakat di Desa Tuka, Buduk, Dalung, dan sekitarnya (Patriwirawan, 1974: 1399).

- Masyarakat Tionghoa. Keberadaan masyarakat Tionghoa di Bali sudah berlangsung sejak masa lampau. Diperkirakan datang sekitar abad ke-7 pada masa kerajaan Bali Kuna untuk mengadakan kontak perdagangan. Legenda yang berkaitan dengan keberadaan etnis Tionghoa di Bali terungkap dalam cerita Raja Balingkang yang terletak di pesisir Danau Batur Kintamani Bangli. Penggalan legenda tersebut menceritakan tentang perkawinan Raja Jayapangus atau Jayasakti yang memerintah Bali pada tahun 1178-1181 Masehi dengan seorang putri Cina yang menetap di Balingkang (Sirikan, 1956: 69). Sampai saat ini etnis keturunan Tionghoa yang tinggal di daerah Kintamani Bangli dianggap sebagai etnis Tionghoa pertama yang menetap di Bali.

Etnis-etnis di atas mendiami beberapa wilayah di Bali baik wilayah pesisir, perkotaan, dan pedesaan. Keberadaan masing-masing etnis tersebut memunculkan kantong-kantong etnis tertentu ditemukan di sejumlah wilayah
Bali. Kehidupan multietnis dan multikultur demikian dijumpai pada beberapa wilayah di Bali baik di wilayah pesisir, wilayah perkotaan, dan di daerah pedalaman atau di pedesaan. Masyarakat pesisir umumnya merupakan keturunan masyarakat Etnis Bugis yang bermata pencaharian sebagai nelayan. Di daerah perkotaan etnisitas yang mendukung masyarakat minoritas bukan semata-mata dari unsur etnis Bugis, tetapi juga ada dari masyarakat Jawa, Madura, Sasak, Arab, Cina (Tionghoa), yang bermata pencaharian sebagai pedagang. Sedangkan di daerah pegunungan umumnya merupakan keturunan masyarakat Bugis dan bermata pencaharian sebagai petani. Kondisi demikian dapat ditemukan dalam kehidupan masyarakat Bugis di Desa Pegayaman Kabupaten Buleleng, Dusun Angantiga Desa Petang Kabupaten Badung, di Desa Medewi Kabupaten Jembrana. Selain itu, juga di Kabupaten Karangasem Bali juga dijumpai masyarakat Suku Sasak yang bermata pencaharian sebagai petani seperti di Desa Sinduwati Kecamatan Sidemen, Desa Saren Jawa, Desa Kecicang, dan Desa Ujung. Tiga desa terakhir berada di Kecamatan Kota Karangasem, yang leluhurnya merupakan tadtadan (prajurit bawaan) ketika terjadi invasi Kerajaan Karangasem Bali ke Pulau Lombok

Pada umumnya, semua komponen etnis dan agama yang bermukin di Bali dapat hidup berdampingan dengan etnisetnis lain yang berbeda agama. Masyarakat etnis Bali selaku etnis mayoritas umumnya dapat menerima keberadaan masyarakat enis lain di sekitarnya karena adanya latar belakang sejarah dan peran para penguasa pada zamannya. Misalnya, keberadaan masyarakat Bugis di Desa Pegayaman maupun di Desa Petang merupakan balas jasa pihak penguasa (raja) atas jasa-jasa mereka. Atas amanat penguasa (raja) pada masa itu, mereka diberi tempat bermukim dan tanah garapan berdampingan dengan masyarakat lokal. Mereka ditata untuk hidup berdampingan dan bekerjasama 
mengelola sumber daya alam untuk kesejahteraan hidup bersama. Dengan demikian, eksistensi kehidupan multietnis telah tertata dalam satu kesatuan organisasi subak sejak masa lampau. Kerjasama organisasi subak diatur sedemikian rupa agar berjalan sesuai esensi organisasi subak yang mayoritas didukung masyarakat Bali beragama Hindu dengan upacara-upacara tertentu sesuai adat kebiasaan masyarakat Hindu. Seluruh kegiatan subak dilakukan bersama-sama mulai dari kegiatan pemeliharaan saluran air, pemilihan perangkat pemimpin subak, dan pengaturan keuangan subak. Kecuali pelaksanaan upacara yang dilakukan sesuai aturan adat dan budaya masyarakat Bali yang beragama Hindu.

\section{Identitas Subak}

Hampir semua wilayah pertanian di Bali memiliki lembaga subak. Pada awal tahun 1990 jumlah subak di Bali tercatat 1.402 subak (Departemen Pekerjaan Umum, 1990:15). Dalam kurun waktu 20 tahun terakhir ini jumlah subak diperkirakan menyusut drastis karena perubahan fungsi lahan pertanian menjadi lahan pemukiman. Hal ini menyebabkan semakin menyempitnya wilayah subak, bahkan tidak sedikit organisasi subak yang mati. Kondisi demikian terjadi di wilayah perkotaan dan daerah-daerah yang menjadi kawasan pembangunan dan pengembangan fasilitas pariwisata.

Keberadaan subak terikat erat dengan tujuh unsur kehidupan masyarakat Bali yang dikemukakan Geertz dalam Utomo (1989:2) yakni; 1) Kewajiban melakukan terhadap pura tertentu. 2) Tempat tinggal. 3) Wilayah pertanian. 4) Sistem kasta atau wangsa. 5) Ikatan kekerabatan. 6) Keanggotaan suatu sekeha (kelompok sosial tertentu). 7) Kesatuan administrasi. Dewasa ini, subak memiliki ciri-ciri dasar sebagai berikut; 1) Merupakan organisasi petani yang mengelola irigasi untuk seluruh anggotanya. 2) Mempunyai sumber air bersama, 3) Mempunyai suatu areal persawahan. 4) Mempunyai otonomi internal maupun eksternal. 5) Mempunyai tempat pemujaan yang berhubungan dengan subak disebut Pura Bedugul (Zuhdi, ed. 1998:104-105). Subak memiliki hak otonom untuk mengatur diri secara luas dengan tujuan menjamin pembagian air yang merata untuk meningkatkan kesejahteraan para anggotanya (Utomo, 1989:2).

Subak mengatur sistem pertanian yang tertuang dalam awig-awig subak (peraturan subak) meliputi beberapa unsur yakni ;

\section{1) Jaringan irigasi}

Pembuatan jaringan irigasi diperhitungkan dengan cermat menerapkan aturan tradisional. Jaringan irigasi subak terdiri atas; (1) Empelan (bendungan), merupakan sumber air utama beberapa wilayah subak. Empelan dibuat dengan membendung aliran sungai menggunakan batu-batu sungai, tumpukan batang pohon kelapa, dan dedaunan. Saat ini empelan dibuat permanen menggunakan batu, pasir, semen, dan beton. (2) Aungan, terowongan air yang dibuat di bawah permukaan tanah. Aungan merupakan saluran air utama yang mengalirkan air dari empelan menuju areal subak. Biasanya dibuat untuk mengalirkan air pada lahan sawah yang dihalangi bukit. Pembuatan aungan direncanakan dengan matang dan dilengkapi lubang udara ke atas disebut bindu dan lubang udara ke samping disebut calung. (3) Telabah, merupakan saluran air yang dibuat terbuka di atas permukaan tanah. Telabah terbagi menjadi dua jenis yakni; telabah gede (saluran air utama atau saluran primer yang mengalirkan air dari empelan menuju beberapa wilayah subak) dan telabah pemaron (saluran air sekunder yang membagi pasokan air menuju areal subak tertentu). Telabah alit (saluran air tersier untuk mengalirkan air menuju petak-petak sawah). Tali kunda (saluran air kuarter yang digunakan untuk mengaliri sawahsawah yang jauh dari saluran air utama, biasanya dibuat berupa saluran kecil 
melalui sawah milik perorangan). Telabah pengutangan (saluran pembuangan kelebihan air yang dialirkan kembali ke sungai). (4) Tembuku, bangunan pembagi air yang terdapat pada telabah atau saluran air. Ukuran pembagian air dibuat berdasarkan ukuran tertentu sesuai kesepakatan dan luas areal subak yang dialiri air. Jenis tembuku atau bangunan pembagi air ini terbagi menjadi tembuku aya (saluran pembagi air utama yang berfungsi mengatur pembagian air ke beberapa wilayah subak). Tembuku pemaron (saluran pembagi yang terdapat pada saluran air sekunder). Tembuku alit atau daanan (pembagi air yang terdapat pada saluran tersier untuk mengatur pembagian air menuju petak-petak sawah).

\section{2) Pola tanam dan masa panen}

Pola tanam dan masa panen diatur sesuai hasil kesepakatan dalam sangkep krama subak (rapat anggota subak) dengan memperhatikan keadaan musim, iklim, dan perhitungan sasih (perhitungan waktu berdasarkan peredaran bulan). Subak mengenal dua pola tanam yakni; (1) Kerta masa, adalah pola tanam yang menerapkan penanaman padi secara serentak dengan waktu bersamaan. Biasanya diterapkan pada wilayah persawahan yang memiliki pasokan air berlimpah. Pola ini dilakukan untuk menghindari serangan hama tikus dan mempermudah kerjasama pengolahan sawah. (2) Kerta gadon adalah pola tanam yang tidak beraturan karena dipengaruhi keadaan musim, sebagian petani menaman palawija, ada pula petani yang membiarkan lahannya eneng (kosong tanpa ditanami). Kerta gadon dilakukan ketika cuaca tidak mendukung dan pasokan air terbatas. (3) Tulak sumur, pola tanam yang tidak beraturan dan tidak memperhatikan musim. Biasanya terdapat pada areal subak di wilayah perkotaan dan mempunyai lahan pertanian sempit.

3) Organisasi subak
Organisasi subak menjalankan tugas secara profesional menyerupai organisasi moderen. Masing-masing divisi menjalankan tugas sesuai bidang tugasnya. Subak diorganisir dalam pengurus subak terdiri atas; (1) Pemimpin subak disebut pekaseh atau kelian subak. (2) Sekretaris subak disebut penyarikan. (3) Bendahara disebut panengen atau juru raksa. (4) Pelaksana tugas koordinasi ke bawah disebut juru arah atau saya. (5) Subak yang wilayahnya cukup luas dibagi-bagi menjadi beberapa kelompok wilayah disebut tempek, munduk, lanyahan, atau banjaran dipimpin seorang kelian tempek, atau kelian munduk, kelian lanyahan, atau kelian banjaran. Para kelian ini bertanggung jawab langsung kepada pemimpin subak. (6) Anggota subak disebut krama subak, terbagi menjadi tiga yakni; krama pengarep (anggota terlibat aktif melaksanakan kegiatan subak), krama pengampel atau krama penyuwinih (anggota pasif yang tidak terlibat langsung dalam kegiatan subak), dan krama leluputan (anggota kehormatan yang dibebaskan dalam kegiatan subak).

\section{4) Upacara}

Organisasi subak memiliki beberapa tempat pemujaan yang berada di beberapa sumber air antara lain; Pura Ulun Danu (tempat pemujaan yang berada di sekitar danau), Pura Ulun Empelan (tempat pemujaan yang terdapat di sekitar bendungan), dan Pura Bedugul (tempat pemujaan yang terdapat di saluran air utama). Pelaksanaan upacara di tempat tersebut dilaksanakan secara kolektif oleh anggota subak yang beragama Hindu. Beberapa upacara kolektif berkaitan dengan aktivitas subak antara lain; magpag toya (upacara pada saat mulai menaikkan air ke sawah), neduh (upacara memohon hujan dan keselamatan menjelang musim tanam), ngusaba (upacara menjelang panen atau pasca panen).

Sesungguhnya subak merupakan organisasi yang memiliki produktivitas, manajemen, demokrasi, dan ekologis. 
Keunggulan subak ada pada pengelolaan organisasi, pembagian air yang merata, pemilihan pemimpin yang demokratis, memperhatikan aspirasi anggota, penerapan toleransi, kesamaan hubungan antaranggota. Namun, sejalan dengan perkembangan zaman, organisasi subak yang unggul dalam waktu tertentu belum tentu unggul apabila tidak dilakukan perbaikan sesuai tuntutan zaman (Sumarta, 1992: 84). Terutama organisasi subak yang anggotanya mengarah pada keberagaman etnis dan agama. Oleh sebab itu, toleransi masing-masing etnis dan agama sangat mendukung keunggulan organisasi subak.

\section{Bentuk-Bentuk Toleransi dalam Organisasi Subak}

Organisasi subak pada beberapa tempat di Bali, bukan hanya beranggotakan masyarakat Bali yang beragama Hindu, tetapi juga masyarakat non-Hindu, terutama anggota masyarakat yang memiliki areal pertanian di wilayah tersebut dan menggeluti sektor pertanian. Dalam kondisi demikian aspek toleransi menjadi agenda utama yang ditaati seluruh anggota. Toleransi adalah aspek kepribadian manusia yang berhubungan dengan emosi. Toleransi yang dilaksanakan dengan benar dapat menghasilkan tiga dimensi kedamaian yakni; a) Tidak ada perselisihan aktif. b) Tidak ada pertikaian dan permusuhan. c. Ada rasa ketenangan (Suacana, 2005:7). Walaupun ketiga hasil toleransi tersebut sulit ditemukan dalam kehidupan masyarakat dewasa ini, organisasi subak memiliki tiga dimensi kedamaian tersebut.

Toleransi dan kerjasama antar anggota subak pada masyarakat multietnis dan multiagama berlangsung secara alamiah tanpa memandang golongan ataupun agama. Baik masyarakat Hindu maupun non-Hindu tercatat sebagai anggota suatu organisasi subak, apabila memiliki lahan dan mengerjakan sawah atau pun tegalan pada wilayah subak tertentu. Bahkan tidak tertutup kemungkinan mereka tergabung dalam organisasi subak maupun subak abian sekaligus, jika memiliki uma atau carik (lahan basah atau sawah) dan abian atau tegal (lahan kering) di lingkungan subak tertentu. Di sini, toleransi dan kerjasama tampak menonjol dalam berbagai aktivitas subak, meliputi kegiatan fisik subak, kelembagaan, maupun kegiatan spiritual atau upacara keagamaan.

Masyarakat Bali yang bergama Hindu memang berperan besar dalam aktivitas organisasi subak karena mayoritas masyarakat Bali yang memiliki tanah pertanian. Meskipun demikian, organisasi subak tidak mengurangi arti persatuan antarpetani yang berbeda agama pada kantong-kantong masyarakat multi etnis dan multi agama. Pada situasi dan kondisi masyarakat demikian, faktor kerjasama dikedepankan, dan berusaha mengembangkan nilai-nilai positif yang menguntungkan kedua belah pihak tanpa memandang unsur mayoritas dan minoritas. Nilai-nilai negatif ditanggalkan sejauh mungkin agar tidak merugikan etnis dan agama lain. Semua itu diatur dalam awig-awig (peraturan) subak yang mengatur hak, kewajiban, dan sanksi yang sama untuk setiap anggota.

Kenyataan tersebut menunjukkan bahwa organisasi subak bersifat terbuka, demokratis, toleransi, dan dapat menerima kebinekaan latar belakang sosial budaya anggotanya dalam satu wadah organisasi. Anggota subak memiliki kelenturan pemahaman yang tercermin dalam sikap toleransi yang dimiliki antaranggota berbeda etnis maupun agama. Melalui organisasi subak proses integrasi dapat ditingkatkan menuju arah yang lebih baik. Jadi, satu hal menarik yang dapat dicatat adalah konsep subak yang dapat berlaku universal. Subak merupakan organisasi yang sarat dengan pengaturan ekonomi tradisional, secara struktural dan teknis organisasi tersebut melibatkan seluruh komponen anggotanya.

Meskipun demikian, dominasi anggota mayoritas terhadap anggota 
minoritas pasti ada dalam beberapa aspek kegiatan organisasi subak. Hal ini tidak dapat dihindari karena kenyataan di masyarakat membuktikan bahwa dalam tataran masyarakat yang setara dan demokratis suara terbanyak selalu mengalahkan suara minoritas, kepentingan mayoritas selalu mengalahkan kepentingan minoritas. Hassan Shadily (1993:86-90) berpendapat bahwa apabila terjadi proses sosial dua masyarakat dan kebudayaan pada suatu tempat, maka masyarakat minoritas di daerah tertentu akan mengikuti pola umum kehidupan masyarakat mayoritas. Dengan kata lain, kebudayaan minoritas akan mengikuti pola umum yang berlaku pada masyarakat mayoritas. Kebudayaan minoritas lebih mudah menerima pengaruh dari masyarakat mayoritas meskipun secara khusus tidak menghilangkan ciri-ciri khas kebudayaan minoritas tersebut. Di sinilah pentingnya adaptasi pihak minoritas dan toleransi pihak mayoritas untuk memperoleh ketenteraman, keseimbangan, dan kesejahteraan seluruh anggota subak.

Merunut peristiwa masa lampau, kehidupan multietnis dan multiagama pada masyarakat Bali telah terjadi sejak masa lampau, khususnya pada masa jayanya zaman kerajaan di Bali. Raja-raja di Bali mengangkat masyarakat pendatang (umumnya Etnis Bugis) sebagai pasukan perang kerajaan. Etnis Bugis dikenal sebagai pasukan yang tangguh dan loyal terhadap raja. Beberapa di antaranya mendapat tugas sebagai tameng dada (pelindung kedaulatan wilayah kerajaan) dan ditugaskan di daerah perbatasan. Misalnya masyarakat etnis Bugis di Petang, Medewi, dan Pegayaman, keberadaannya terkait dengan tugasnya sebagai pasukan kerajaan. Sebagai pasukan kerajaan, mereka diberi hak untuk mengelola tanah pertanian untuk memenuhi kebutuhan hidup. Tanah-tanah pertanian tersebut tetap dikelola secara turun-temurun dan keturunan mereka yang bermata pencaharian sebagai petani sampai kini ikut terhimpun dalam organisasi subak bersama masyarakat etnis Bali lainnya.

Dalam pelaksanaan aktivitas subak, baik masyarakat Bali maupun etnis-etnis lain bersama-sama melaksanakan awigawig subak. Di sini unsur-unsur toleransi dipandang penting mengingat masingmasing etnis dan agama memiliki keyakinan berbeda. Mereka berupaya mencari jalan terbaik agar dapat mengakomodir kepentingan semua anggota dan aktivitas pertanian berjalan lancar. Masing-masing bentuk toleransi tersebut dapat dipaparkan dalam beberapa dimensi subak berikut;

\section{a) Bentuk Toleransi dalam Aktivitas Fisik Subak}

Toleransi kegiatan teknis menyangkut pemeliharaan fisik subak meliputi pemeliharaan bangunan milik subak seperti; bale subak (bangunan milik organisasi subak digunakan sebagai tempat rapat subak), pura bedugul (tempat pemujaan yang berkaitan dengan wilayah subak dan pelaksanaan pertanian), empelan (bendungan air), aungan (terowongan air), dan telabah (saluran air). Pemeliharaan bangunan fisik subak melibatkan semua komponen anggota yang berbeda agama, baik masyarakat beragama Hindu, Islam, Kristen, maupun Budha. Toleransi dan kerjasama terkait pemeliharaan fisik subak tampak jelas dalam kegiatan matelik (perbaikan saluran air) maupun pemeliharaan empelan (bendungan air). Sesungguhnya masing-masing anggota subak mendapat tugas-tugas memelihara kondisi fisik subak secara adil dan merata tanpa memandang agama yang dianut, antara lain kelompok yang bertugas mengatur air, memelihara saluran air, maupun memelihara bendungan. Masingmasing kelompok bertanggung jawab atas keadaan bendungan, kelancaran pasokan air, maupun pengaturan pembagian air. Sementara itu, pemeliharaan fisik yang agak berat dan membutuhkan tenaga besar, pembagian kelompok tugas tidak berlaku. Seluruh anggota bekerjasama mengatasi 
pekerjaan tersebut, misalnya perbaikan bendungan jebol atau pun memperbaiki bale subak. Khusus untuk perbaikan pura subak, masyarakat muslim tidak ikut terlibat, perbaikan hanya dilaksanakan oleh pihak anggota yang beragama Hindu. Biaya perbaikan ditanggung bersama, baik masyarakat Hindu maupun masyarakat non-Hindu.

Toleransi dan kerjasama digunakan dalam menyikapi awig-awig (aturan) subak yang mengharuskan masyarakat nonHindu ikut serta membiaya perbaikan pura subak. Padahal secara empiris masyarakat non-Hindu tidak pernah memanfaatkan pura subak untuk melakukan aktivitas relegi. Salah satu contoh, masyarakat Etnis Sasak di Desa Saren Kecamatan Bebandem Kabupaten Karangasem tidak terlibat langsung dalam pemeliharaan fisik subak atau pun hal-hal yang berkaitan dengan perbaikan fasilitas bangunan fisik subak dan pura subak, tetapi mereka tetap memperoleh fasilitas organisasi subak. Sebagai konpensasinya mereka wajib membayar suwinih (iuran) lebih besar dari anggota yang beragama Hindu.

Dalam kondisi demikian status anggota subak dibagi secara tegas menjadi krama pengarep dan krama penyuwinih. Anggota subak non-Hindu yang tidak terlibat dalam sebagian kegiatan subak disebut krama penyuwinih sedangkan anggota yang terlibat sepenuhnya disebut krama pengarep. Pola serupa berlaku pula pada anggota subak di Desa Sinduwati Kecamatan Sidemen Kabupaten Karangasem. Anggota beragama Islam disebut krama penyuwinih dengan membayar suwinih (iuran) penuh, sedangkan anggota beragama Hindu disebut krama pengarep dengan membayar suwuinih separuh dari krama penyuinih. Pembebastugasan anggota subak beragama Islam diperkenankan jika ada perbaikan bangunan pura subak. Mereka tidak terlibat langsung mengerjakan perbaikan bangunan pura subak tetapi wajib membayar peturunan (iuran) berupa sejumlah uang yang telah disepakati bersama melalui sangkep atau rapat anggota subak (Armini, 2002: 32).

\section{b) Bentuk Toleransi Kelembagaan Subak}

Secara umum kelembagaan subak tertata dalam bentuk struktur organisasi sedemikian rupa dipimpin seorang kelian subak atau pekaseh. Dalam menjalankan roda organisasi, kelian subak dibantu beberapa orang perangkat subak terdiri atas, penyarikan (wakil ketua), kasinoman (sekretaris), kelian tempek (ketua kelompok), dan lain-lain. Pada organisasi subak yang anggotanya berbeda etnis dan agama, struktur organisasi dan istilahistilah kelembagaan subak menerapkan pola-pola yang telah disepakati bersama sesuai kondisi masyarakat dan wilayah. Kesepakatan-kesepakatan lembaga subak dalam beberapa hal menampakkan unsurunsur toleransi dan adaptasi, khususnya menyangkut pemilihan pengurus.

Pada prinsipnya seluruh anggota subak memperoleh hak dan kewajiban sama. Secara kelembagaan, kerjasama menyangkut pemilihan pejabat struktural dan teknis organisasi melibatkan seluruh komponen anggota. Anggota subak beragama Hindu maupun non-Hindu bersama-sama memilih pengurus untuk memajukan organisasi serta meningkatkan kesejahteraan anggotanya. Kerjasama yang baik di lingkungan organisasi subak tampak juga dari kekompakan seluruh anggota dalam pemilihan kelian subak atau pekaseh dilandasi asas keadilan dan kebersamaan. Sedapat mungkin pemilihan pengurus diatur agar dapat mewadahi semua kelompok, yakni menempatkan pengurus dari golongan etnis lain yang non-Hindu maupun Hindu secara proporsional. Jika kelian subak atau pekaseh berasal dari masyarakat Hindu maka wakil pekaseh dari masyarakat nonHindu, atau sebaliknya. Selanjutnya mereka bersama-sama menjalankan roda organisasi untuk kepentingan anggota. Namun dalam tahap kelembagaan ini, khususnya kepemimpinan organisasi subak 
jarang diduduki masyarakat non-Hindu. Budaya demokratis lembaga subak memberi peluang lebih besar kepada anggota mayoritas menduduki struktur pimpinan lembaga subak. Meskipun demikian unsur-unsur toleransi tetap ada, yang tampak dari pemberian kesempatan menduduki jabatan tertentu kepada anggota non-Hindu.

Di Desa Angantiga Kecamatan Petang Kabupaten Badung, kerjasama antara anggota subak beragama Hindu dan Islam berlangsung dengan baik. Secara kelembagaan, seluruh anggota berhak mendapat fasilitas pengairan dan berhak pula menikmati keuntungan yang diperoleh organisasi subak. Hasil-hasil pembayaran air disebut suwinih atau pun pengampel dikumpulkan dalam bentuk sejumlah dana tunai, kemudian dibuat sebagai kas bersama. Bagi anggota yang memerlukan bantuan dana diperkenankan meminjam sejumlah uang dari dana tersebut. Apabila ada sisa dana dalam waktu-waktu tertentu, sebagian dana tabungan dicairkan untuk dibagikan kepada masing-masing anggota. Selain untuk kepentingan anggota, sebagian dana bersama itu juga dimanfaatkan untuk memperbaiki fasilitas fisik subak seperti perbaikan saluran air, balai subak, bangunan suci, dan upacara (Armini, 2004: 42).

\section{c) Bentuk Toleransi dalam Upacara Ritual Subak}

Organisasi subak pada kantongkantong masyarakat multietnis dan multiagama di Bali berfungsi sebagai media toleransi. Meskipun ada kecenderungan hegemoni pihak mayoritas untuk menerapkan awig-awig (peraturan subak) dalam kerangka masyarakat Bali dan Agama Hindu. Awig-awig demikian seolah-olah "memaksa" anggota minoritas beradaptasi dalam pelaksanaan upacara secara Hindu. Menurut pandangan anggota subak yang beragama Hindu, pelaksanaan upacara di Pura Subak adalah kewajiban semua anggota yang beragama Hindu.
Pandangan demikian mengharuskan semua anggota (khususnya yang beragama Hindu) terlibat dalam pelaksanaan upacara ritual. Padahal dalam beberapa kasus tidak semua anggota subak beragama Hindu dan tidak semua anggota dapat melakukan upacara Hindu di pura subak.

Dalam kondisi demikian, toleransi seluruh anggota mendukung kelenturan aturan-aturan guna mengakomodir kepentingan semua pihak. Di sini tampak adanya unsur toleransi pihak mayoritas dan minoritas. Anggota subak non-Hindu selaku anggota minoritas secara sukarela menyumbang sejumlah dana tanpa ikut terlibat dalam pelaksanaan upacara tersebut. Di Desa Sinduwati Sidemen Karangasem, anggota subak terdiri atas masyarakat Hindu dan Islam. Kewajiban antara anggota subak yang beragama Hindu dan Islam terbagi secara tegas. Jika ada perbaikan bangunan dan upacara di pura subak, anggota Islam tidak ikut mengerjakannya tetapi tetap berkewajiban membayar peturunan (iuran) berupa uang. Mereka menyerahkan kewenangan penuh kepada anggota yang beragama Hindu. Sistem ini disebut dengan sistem nyerahang kaon, yakni tidak ikut terlibat tetapi tetap membayar iuran dalam jumlah tertentu mengingat upacara tersebut mempunyai tujuan spiritual untuk memohon keselamatan dan kesuburan lahan pertanian (Armini, 2002: 35).

Toleransi dan kerjasama pihak mayoritas maupun minoritas tampak dalam pelaksanaan upacara-upacara tertentu bagi anggota subak di semua wilayah yang memiliki keragaman etnis dan agama, seperti Desa Sinduwati Kecamatan Sidemen Karangasem, Desa Angantiga Kecamatan Petang Badung, Desa Ekasari Kecamatan Melaya Jembrana, Desa Pegayaman Kecamatan Sukasada Buleleng, dan Desa Medewi Kecamatan Pekutatan Jembrana. Di Desa Medewi, upacara magpag toya (upacara menyambut dan menaikkan air dari bendungan untuk pertama kali sebelum musim tanam berlangsung), semua anggota diharapkan 
ikut dalam upacara tersebut. Pada saat upacara magpag toya ini, baik umat Islam maupun Hindu bersama-sama melakukan upacara pada tempat yang berbeda. Anggota Hindu menggelar upacara di Pura Bedugul, di empelan (bendungan), dan di pecipakan yeh (tempat memasukkan air di areal sawah). Sementara itu masyarakat Muslim melakukan selamatan dan berdoa di musholla yang letaknya tidak jauh dari lokasi Pura Bedugul, untuk memohon keselamatan dan kesuburan tanaman (Sudarma, 2001: 122).

Toleransi dan kerjasama antara anggota subak yang beragama Hindu dan Islam juga ditemukan di Desa Pegayaman Kecamatan Sukasada Kabupaten Buleleng, dalam kegiatan khusus dilakukan untuk menyambut datangnya upacara ngusaba. Upacara ngusaba merupakan suatu aktivitas ritual masyarakat Hindu yang pada intinya pengungkapan syukur atas keberhasilan pertanian. Sebelum upacara berlangsung, baik masyarakat Islam maupun Hindu bersama-sama melaksanakan tradisi nganyang (berburu kijang) di hutan sekitarnya untuk dibuat sate gempol dan anyang (sejenis lauk terbuat dari daging cincang yang dicampur kelapa parut). Selanjutnya pelaksanaan upacara ngusaba dilaksanakan sepenuhnya oleh masyarakat Hindu di pura subak, sedangkan umat Islam melangsungkan selamatan di masjid dengan membaca beberapa syair dan doa-doa dalam Kitab Maulid (Purna, 2001: 34).

\section{PENUTUP}

Toleransi dan kerjasama masyarakat mutietnis dan multiagama pada aktivitas subak di Bali saat ini berjalan dengan baik. Masyarakat Bali yang beragama Hindu selaku mayoritas mengedepankan aspek toleransi, sebaliknya masyarakat etnis lain yang beragama non-Hindu mampu beradaptasi dengan keadaan sekitarnya. Meskipun demikian, masyarakat Bali sebagai bagian dari keberagaman Bangsa Indonesia juga tidak terlepas dari persoalan multietnik dan multiagama. Profil kehidupan multietnik, multiagama, dan multibudaya telah ada sejak masa lampau. Masyarakat Bali yang selama ini dikenal sebagai masyarakat homogen di dalamnya menyimpan potensi multietnis, multiagama, dan multibudaya yang relatif kompleks (Wijaya. 2005:36).

Sejak masa lampau masyarakat Bali merupakan masyarakat heterogen yang sudah menerapkan pola kerjasama dan toleransi. Di sela-sela kerjasama dan toleransi tersebut, disertai "sedikit" dominasi pihak mayoritas terhadap minoritas. Gejala demikian selalu ada pada semua kebudayaan di dunia, termasuk dalam kehidupan masyarakat Bali sejak masuknya masyarakat minoritas nonHindu pada masa lampau. Dominasi pihak mayoritas terhadap minoritas didukung oleh pendapat para ahli bahwa apabila dua masyarakat dan kebudayaan berada dalam lokasi yang sama, maka masyarakat minoritas di daerah tertentu akan mengikuti pola umum kehidupan masyarakat mayoritas. Dengan kata lain, kebudayaan minoritas akan mengikuti pola umum yang berlaku pada masyarakat mayoritas. Konsep-konsep demikian memungkinkan munculnya unsur-unsur dominasi pihak mayoritas terhadap pihak minoritas dalan tataran organisasi subak di Bali.

Pandangan tentang keuniversalan dan kedemokratisan lembaga subak di Bali memang benar dan nyata adanya. Bahwa subak merupakan organisasi tradisional yang demokratis, universal, serta mampu menyadari kepentingan seluruh anggotanya. Namun di balik kedemokratisan tersebut, tampak adanya unsur-unsur dominasi dalam beberapa hal, terutama lembaga subak pada kantongkantong masyarakat multietnis dan multiagama. Contoh nyata dominasi tersebut tampak dalam tataran fisik, kelembagaan, dan upacara subak. Terlebihlebih pada tataran upacara ritual yang dilakukan di pura subak, pembiayaan upacara dibebankan pada seluruh anggota, sedangkan pelaksanaannya dilakukan oleh 
masyarakat Hindu saja dan masyarakat non-Hindu tidak terlibat.

Kondisi demikian dalam jangka waktu lama di masa-masa mendatang dapat menimbulkan konflik internal yang mengarah pada disintegrasi dan perpecahan di masyarakat. Oleh sebab itu perlu dilaksanakan berbagai kebijakan yang mengakomodir semua kepentingan tanpa meninggalkan aspirasi dan kepentingan pihak minoritas. Beberapa saran yang dapat dikemukakan untuk menghindari terjadinya konflik akibat adanya dominasi pihak mayoritas terhadap pihak minoritas dalam tataran subak antara lain;

- Memberi pemahaman multikultur pada masyarakat heterogen karena pemahaman akan pendidikan multikultur itu sendiri merupakan upaya untuk menunbuhkan kesadaran akan adanya perbedaan di masyarakat. Baik melalui pendekatan personal (dimulai dari diri sendiri) maupun segenap komponen masyarakat.

- Penerapan toleransi dan kerjasama sangat penting bagi masyarakat multietnis dan multiagama. Hal ini dapat dicapai dengan membuka peluang kesadaran bahwa perbedaan etnis, budaya, dan agama adalah suatu sifat universal. Usaha-usaha menggugah kesadaran bertoleransi perlu digali lebih jauh untuk menumbuhkan hubungan positif suatu agama dengan agama lain. Setidaknya kajian tentang multikultur memberi pemahaman bahwa setiap agama pada hakikatnya mempunyai tujuan akhir sama yakni mencapai kualitas hidup lebih baik. Beberapa filsuf mengatakan bahwa agama merupakan usaha kolektif dan kerja sama manusia untuk dapat menjadi manusia bijaksana, sehingga agama dan budaya di masyarakat tidak harus dipertentangkan.

- Menanamkan nilai-nilai kebersamaan yang telah terbina selama ini kepada generasi penerus untuk mencegah perpecahan antara masyarakat berbeda etnik dan agama di Bali. Sebab, perpecahan bisa saja muncul sejalan dengan dinamika budaya dan persaingan hidup yang semakin ketat. Dengan demikian pikiran jernih, sikap arif, dan bijaksana dalam pergaulan sehari-hari perlu dikembangkan dalam menghadapi ketatnya persaingan hidup di kalangan masyarakat multikultur.

- Mencegah pandangan superior dan inferior yang memandang bahwa pihak dominan sebagai superior dan pihak minoritas sebagai inferior. Pandangan demikian dapat ditangkal melalui pembinaan kesadaran bahwa suatu budaya satu dengan lainnya ada unsurunsur saling mempengaruhi. Dengan demikian adalah sangat tidak beralasan apabila salah satu agama merasa superior dari agama lainnya, bahkan dalam konteks tujuan agama, setiap agama mengarahkan tujuan mulia yakni memperbaiki kualitas kehidupan manusia.

- Mengcegah provokasi pihak luar yang ingin memecah belah kerukunan yang telah terbina selama ini, dengan mewaspadai beberapa sikap masyarakat yang mengadu domba masing-masing kelompok masyarakat.

\section{DAFTAR SUMBER}

Armini, I Gusti Ayu. 2002.

"Akulturasi Budaya (Islam-Hindu) di Kampung Sindu Desa Sinduwati Kecamatan Sidemen Karangasem" dalam Jurnal Penelitian Sejarah dan Nilai Tradisional Edisi Kedua No.05/II/2002 Tahun 2002. Departemen Pendidikan Nasional Direktorat Jenderal Kebudayaan Balai Kajian Sejarah dan Nilai Tradisional Denpasar. 2004. 
"Profil Kerukunan Umat beragama di Dusun Angantiga Desa Petang Kabupaten Badung" dalam Jurnal Penelitian Sejarah dan Nilai Tradisional Edisi keempatbelas No.14/IV/2004 Tahun 2004. Departemen Kebudayaan dan Pariwisata Balai Kajian Sejarah dan Nilai Tradisional Bali, NTB, NTT. 2006.

"Akulturasi Budaya Hindu-Katolik Pada Masyarakat Katolik di Kampung Sindu Desa Ekasari Kecamatan Melaya Kabupaten Jembrana" dalam Jurnal Penelitian Sejarah dan Nilai Tradisional Edisi Kduapuluhlima No.25/VI/2006 Tahun 2006. Departemen Kebudayaan dan Pariwisata Balai Kajian Sejarah dan Nilai Tradisional Bali, NTB,NTT.

Departemen Pekerjaan Umum. 1990.

Subak. Denpasar: Kanwil

Departemen Pekerjaan Umum Provinsi Bali.

Koentjaraningrat.1980.

Sejarah Teori Antropologi I. Jakarta: UI Press.

Melalatoa, D. J. 1995.

Ensiklopedi Suku Bangsa di Indonesia. Jakarta: Departemen Pendidikan dan Kebudayaan.

Patriwirawan SVD, P. 1974.

"Sejarah Gereja Katolik di Wilayah Keuskupan Denpasar" dalam Sejarah Gereja Katolik Indonesia. Jakarta: Bagian Dokumentasi Penerangan Kantor Waligereja Indonesia.

Purna, I Made. 2001.

"Budaya Masyarakat Perbatasan (Studi Kasus Desa Pegayaman Buleleng)" dalam Jurnal Penelitian Sejarah dan Nilai Tradisional Edisi
Kedua No.02/I/2001 Tahun 2001. Departemen Pendidikan Nasional Direktorat Jenderal Kebudayaan Balai Kajian Sejarah dan Nilai Tradisional Denpasar.

Shadily, Hassan. 1993.

Sosiologi untuk Masyarakat

Indonesia. Jakarta: Rineka Cipta.

Sirikan, Gora. 1956.

Sejarah Balirajya. Naskah stensilan.

Suacana, I Wayan Gede. 2005.

"Diferensiasi Sosial dan Penguatan Toleransi dalam Masyarakat Multikultural" dalam Jurnal Kajian Budaya No.3 Volume 2 Januari 2005. Denpasar: Program Studi Magister Kajian Budaya Universitas Udayana.

Sudarma, I Wayan. 2001

"Kajian Antaretnik dalam Pelaksanaan Upacara Tradisional di Pura Subak Medewi Jembrana" dalam Jurnal Penelitian Sejarah dan Nilai Tradisional Edisi Pertama No.01/I/2001 Tahun 2001. Departemen Pendidikan Nasional Direktorat Jenderal Kebudayaan Balai Kajian Sejarah dan Nilai Tradisional Denpasar.

Sumarta, Ketut. 1992.

Subak Inspirasi Manajemen

Pembangunan Pertanian. Denpasar:

Citra Budaya.

Tsang, To Hang. 1979.

Sejarah Perintis Penginjilan di Bali. Jakarta: Rev. John Zakariah.

Utomo, Sri Saadah. (ed.). 1989.

Sistem Subak di Bali. Jakarta:

Departemen Pendidikan dan

Kebudayaan. 
Wijaya, Nyoman. 2005.

"Budaya dan Masyarakat Bali dalam Perspektif Multikulturalisme" dalam Jurnal Kajian Budaya No.3 Volume 2 Januari 2005. Denpasar: Program Studi Magister Kajian Budaya Universitas Udayana.
Zuhdi, Susanto (ed.). 1998.

Sejarah Kebudayaan Bali: Kajian Perkembangan dan Dampak Pariwisata. Jakarta: Departemen Pendidikan dan Kebudayaan. 